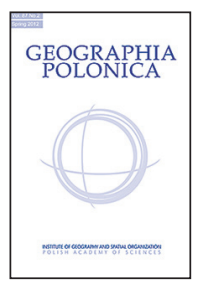

\title{
DELIMITATION AND TYPOLOGY OF FUNCTIONAL URBAN REGIONS IN POLAND BASED ON COMMUTING, 2006
}

\author{
Przemysław Śleszyński \\ Institute of Geography and Spatial Organization \\ Polish Academy of Sciences \\ Twarda 51/55, 00-818 Warsaw: Poland \\ e-mail: psleszyn@twarda.pan.pl
}

\begin{abstract}
This study presents the delimitation of functional urban regions in Poland modified using the Nyusten-Dacey method based on the data regarding commuting in 2006. The modification involved establishing an administrative and settlement hierarchy to serve as the basis on which the order of precedence of flows to individual communes was determined, and supplementing it with the combination of inflows and outflows in a given hub region. A total of 456 individual regions were isolated, including 1 capital region, 21 regional, 54 sub-regional, 212 local (powiat), and 168 other local regions.
\end{abstract}

\section{Key words}

functional urban region - daily urban system - commuting - Nystuen-Dacey method

The research into daily urban systems, initiated in the 1970s, brought many delimitations of functional urban regions and, generally, functional urban areas. They were usually distinguished based on the analyses of commuting ranges. On the basis of this measure in Poland, such delimitations were developed, above all, by Korcelli $(1977,1981)$ and Potrykowska (1989).

After 1989, research into the range of influence of cities became more difficult across the country due to the lack of appropriate data concerning the every-day oscillatory movements to work and services. No thorough studies into mobility which could answer the question about the scale and range of staff commuting were included in any countrywide population census either. The attempts made involved only delimitation based on fragmentary data for separate regions for the country (e.g. Zborowski 2004; Hołowiecka \& Szymańska 2008). Only as late as 2008, 
the Centre for City Statistics of the Statistical Office in Poznan, in cooperation with the Ministry of Finance, launched research into this phenomenon based on tax returns for 2006 (Kruszka 2010). It is so because under the Polish law those who take up employment away from their habitual residence, are entitled to deductible expenses.

The method used by the Central Statistical Office and Ministry of Finance is not without its weak points resulting from the nature of the source material, i.e. individual income tax returns filed by the taxpayers; among others, it does not include about $20-25 \%$ of all commuting, and those included sometimes contain errors ensuing from the definition of registration and the location of the company headquarters in relation to its production and service branches, etc. (Śleszyński 2012). In their general scope, however, these data allow to a large extent to grasp the main regularities related to every-day commuting. This is why in the recent years in Poland, there have been more delimitation works (concerning suburban zones, functional urban areas) which use the above-mentioned data on staff commuting (Guzik et al. 2010; Guzik 2012; Śleszyński 2013).

The delimitation of the influence ranges of cities based on commuting is invariably one of the best and most efficient methodological solutions. This is due to the commonness and frequency as well as high volume of movements. Commuting is cyclical, occurs in a daily rhythm, and involve a relatively large population group, functionally linked to the centre towards which it moves.

For the purpose of delimitation of functional urban regions the Nystuen and Dacey (1961) approach was adapted, in particular, which involves prioritizing of all relations from a given commune to others, from the largest to the smallest volume-wise, and then assigning the highest relations to the corresponding commuting destination units. This methods selects the communes which gravitate the most towards the individual larger centres showing labour demand and gathering commuting. Also, a principle of exclusion is applied, which allows each commune to only be assigned to a single other commune. Subsequently, groupings of communes belonging to centres were determined according to the administrative and settlement hierarchy. The same procedure was performed twice, once for departures and once for arrivals. The described method allowed to isolate 456 individual regions in the country, including one capital region (A), 21 regional (B), 54 sub-regional (C), 212 local powiat regions (D), and 168 other local ones.

The combination of both classification methods - the hierarchy of centres and the volume of inflows (arrivals) and outflows (departures) provided further basis for the development of a typology. Overall, the introduced modification of the Nystuen-Dacey method involved using a way of determining the order of precedence of individual communes, supplementing it with the combination of inflows and outflows in a given hub region.

The performed delimitation shows that the strongest influence logically pertains to the most developed labour markets and decreases with the distance to the development centres. However, due to the effect of various factors, the range of this influence is not uniform and results in numerous deformations. Because of this, the shape of areas gravitating to individual centres is not circular but rather takes varied shapes.

In Poland, the size of the ranges of influence does not conform to the functional and settlement hierarchy (Tab. 1). The largest regions, apart from Warsaw, belong among others to Poznań, and then to cities lying outside of the traditionally strongest group of centres (Białystok and Szczecin). They are followed, according to the area they cover, by the cities belonging to the first five in terms of the population count (Krakow, Łódź, Wrocław, Tricity). This ensues from the peculiar characteristics of the distribution of the largest cities nationwide.

\section{Editors' note:}

Unless otherwise stated, the sources of tables and figures are the author(s), on the basis of their own research. 
Table 1. Characteristic features related to the size and mobility (commuting) of the distinguished functional urban regions (FUR) of Poland in 2006

\begin{tabular}{|c|c|c|c|c|c|c|c|c|}
\hline \multirow[b]{2}{*}{$\begin{array}{l}\text { Main city } \\
\text { of the region }\end{array}$} & \multicolumn{3}{|c|}{ Population } & \multirow[b]{2}{*}{$\begin{array}{c}\text { Area } \\
(\mathrm{sq} . \mathrm{km})\end{array}$} & \multicolumn{4}{|c|}{ Daily mobility (commuting) } \\
\hline & $\begin{array}{c}\text { total } \\
\text { (in thous.) }\end{array}$ & $\begin{array}{l}\text { in work- } \\
\text { ing age } \\
(\%)\end{array}$ & $\begin{array}{c}\text { in the } \\
\text { core } \\
\text { (main city, } \\
\text { in thous.) }\end{array}$ & & $\begin{array}{c}\text { total } \\
\text { (in thous.) }\end{array}$ & $\begin{array}{l}\text { relation } \\
\text { to } 1000 \\
\text { persons } \\
\text { in work- } \\
\text { ing age }\end{array}$ & $\begin{array}{c}\text { inflow } \\
\text { (in thous.) }\end{array}$ & $\begin{array}{c}\text { inflow } \\
\text { to the } \\
\text { core } \\
\text { (main city, } \\
\text { in thous.) }\end{array}$ \\
\hline Warsaw & 5,238 & 65.1 & 1,702 & 19,485 & 561.8 & 165 & 246.0 & 104.2 \\
\hline Katowice ${ }^{\star}$ & 1,600 & 65.9 & 1,991 & 3,406 & 251.5 & 238 & 127.9 & 63.7 \\
\hline Poznań & 1,042 & 65.6 & 565 & 7,266 & 201.4 & 294 & 105.5 & 40.6 \\
\hline Wrocław & 734 & 65.6 & 635 & 5,737 & 97.6 & 203 & 50.4 & 19.5 \\
\hline Bydgoszcz & 726 & 65.6 & 363 & 4,791 & 66.3 & 139 & 34.0 & 12.8 \\
\hline Lublin & 690 & 62.9 & 353 & 5,662 & 63.7 & 147 & 35.5 & 16.9 \\
\hline Krakow & 677 & 62.7 & 756 & 3,686 & 106.5 & 251 & 66.7 & 35.6 \\
\hline Łódź & 568 & 64.3 & 760 & 3,045 & 66.6 & 182 & 39.2 & 17.5 \\
\hline Opole & 561 & 65.2 & 128 & 4,314 & 59.5 & 163 & 32.1 & 11.3 \\
\hline Tricity & 529 & 64.3 & 748 & 3,233 & 74.6 & 219 & 45.9 & 25.7 \\
\hline Kielce & 500 & 63.4 & 207 & 4,083 & 57.8 & 182 & 31.5 & 13.0 \\
\hline Szczecin & 494 & 66.4 & 409 & 6,898 & 43.6 & 133 & 24.9 & 10.2 \\
\hline Rzeszów & 432 & 62.2 & 164 & 2,378 & 84.6 & 315 & 43.2 & 23.0 \\
\hline Białystok & 314 & 61.4 & 295 & 6,436 & 23.3 & 121 & 14.1 & 8.3 \\
\hline Olsztyn & 296 & 64.3 & 175 & 6,415 & 25.5 & 134 & 15.7 & 6.7 \\
\hline Zielona Góra & 275 & 65.7 & 118 & 3,099 & 41.3 & 228 & 20.8 & 7.5 \\
\hline Bielsko-Biała & 259 & 63.9 & 176 & 719 & 64.5 & 390 & 35.8 & 3.6 \\
\hline Częstochowa & 211 & 62.5 & 245 & 2,440 & 31.2 & 237 & 21.1 & 10.9 \\
\hline Toruń & 146 & 63.4 & 207 & 1,734 & 15.0 & 163 & 10.1 & 5.7 \\
\hline Radom & 146 & 61.8 & 226 & 1,372 & 11.3 & 126 & 7.9 & 3.8 \\
\hline $\begin{array}{l}\text { Gorzów } \\
\text { Wielkopolski }\end{array}$ & 131 & 65.1 & 126 & 3,084 & 10.8 & 127 & 6.0 & 2.1 \\
\hline Rybnik & 103 & 64.7 & 299 & 287 & 20.4 & 308 & 13.1 & 2.4 \\
\hline Total & 15,669 & 64.7 & 10,648 & 99,571 & $1,978.9$ & 195 & $1,027.3$ & 444.9 \\
\hline
\end{tabular}

* connurbation: Bytom, Chorzów, Dabrowa Górnicza, Gliwice, Jaworzno, Katowice, Mysłowice, Piekary Śląskie, Ruda Śląska, Siemianowice Ślaskie, Sosnowiec, Świętochłowice, Tychy, Zabrze.

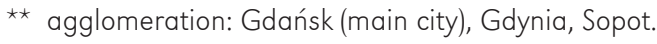




\section{References}

GuzIK R. (ed.), 2012. Czynniki i ograniczenia rozwoju miast województwa pomorskiego w świetle relacji przestrzennych i dostępności komunikacyjnej. Kraków: Uniregio.

Guzik R., Zborowski A., KoŁoś A., Micek G., Gwosdz K., Trzepacz P., Chaberko T., Kretowicz P., Ciechowski M., Dej M., Grad N., 2010. Dostępność komunikacyjna i powiqzania miast oraz delimitacja obszarów funkcjonalnych [in:] Małopolskie miasta - funkcje, potencjał i trendy rozwojowe. Kraków: Małopolskie Obserwatorium Polityki Rozwoju, pp. 88-134.

HoŁoWIECKA B., SzYMAŃSKa D., 2008. The changes in the functional urban region in the new socio-economic conditions in Poland. The case of Toruń. Bulletin of Geography. Socio-economic series, no. 9, pp. 63-78.

KorCelli P., 1977. An approach to the analysis of functional urban regions: A case study of Poland. IIASA Research Memorandum RM-77-052, Laxenburg, http://www.iiasa.ac.at/ publication/more_RM-77-052.php [19 September 2013].

KorCeluI P., 1981. Regiony miejskie w systemie osadniczym Polski [in:] K. Dziewoński, P. Korcelli (eds.), Studia nad migracjami i przemianami systemu osadniczego w Polsce. Prace Geograficzne, 140,
Warszawa: Instytut Geografii i Przestrzennego Zagospodarowania, pp. 189-212.

KRUsZKA K. (ed.), 2010. Dojazdy do pracy w Polsce. Poznań: Ośrodek Statystyki Miast, Oddział GUS w Poznaniu.

Nystuen J.D., DaCEY M.F., 1961. A graph theory interpretation of nodal regions. Papers and Proceedings of the Regional Science Association, 7, pp. 29-42.

POTRYKOWSKA A., 1989. Funkcjonalne regiony miejskie w krajowym systemie osadniczym [in:] P. Korcelli, A. Gawryszewski (ed.), Współczesne przemiany regionalnych systemów osadniczych w Polsce. Prace Geograficzne, 152, Warszawa: Instytut Geografii i Przestrzennego Zagospodarowania PAN, pp. 55-76.

ŚLESZYŃSKI P., 2012. Kierunki dojazdów do pracy. Wiadomości Statystyczne, 11, pp. 59-75.

ŚLESZYŃSKI P., 2013. Delimitacja Miejskich Obszarów Funkcjonalnych stolic województw. Przegląd Geograficzny, vol. 85, no. 2, pp. 173-197.

ZBorowski A. 2004. Podejście funkcjonalno-strukturalne w badaniach delimitacji obszarów metropolitalnych w Polsce (przykład Krakowa) [in:] J. Słodczyk (ed.), Przemiany struktury przestrzennej miast w sferze funkcjonalnej i społecznej. Opole: Uniwersytet Opolski, pp. 25-39. 


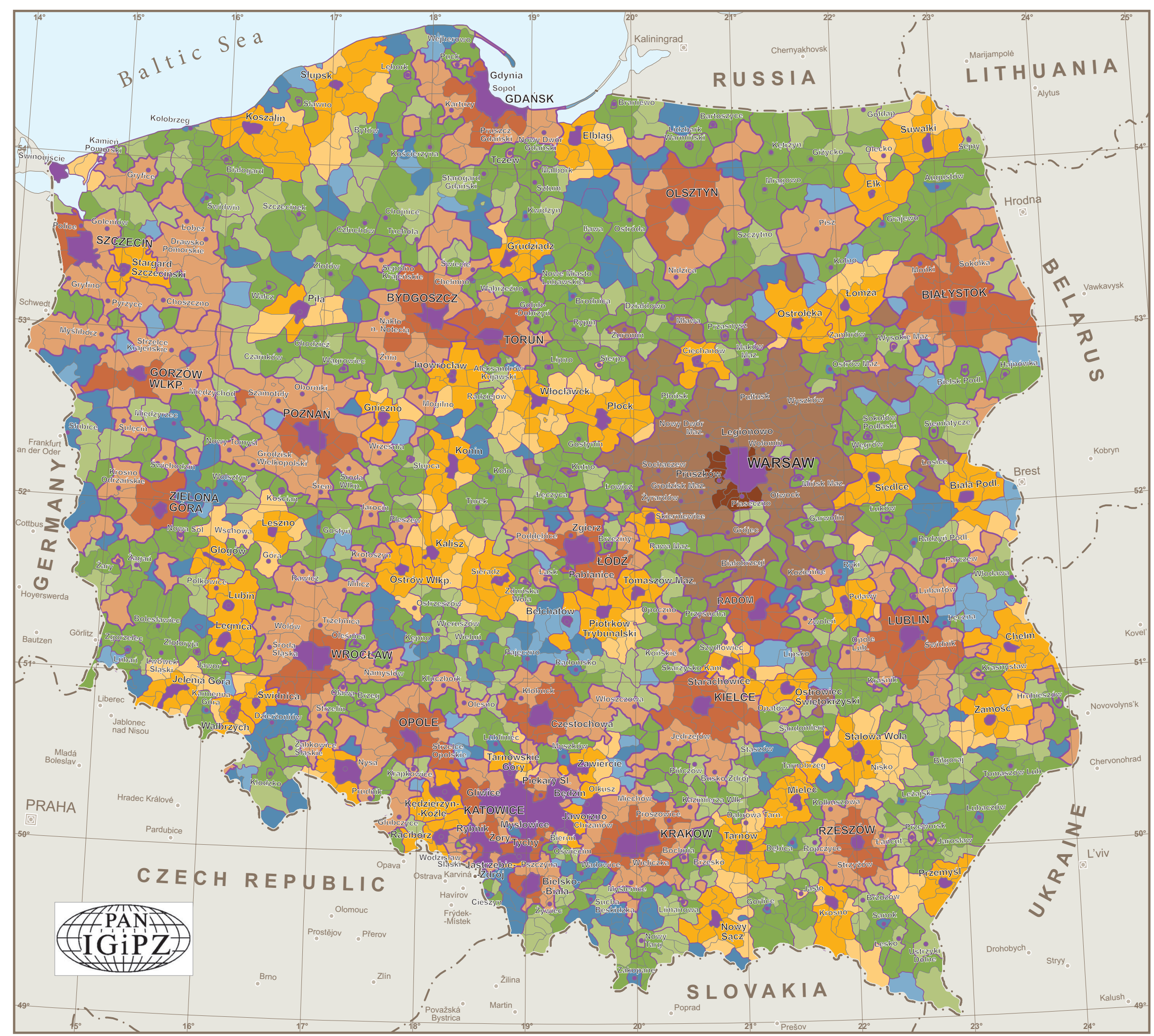

DELIMITATION AND TYPOLOGY OF FUNCTIONAL URBAN REGIONS IN POLAND BASED ON COMMUTING, 2006 by Przemysław Sleszyński

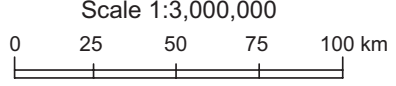

Types of administrative centers
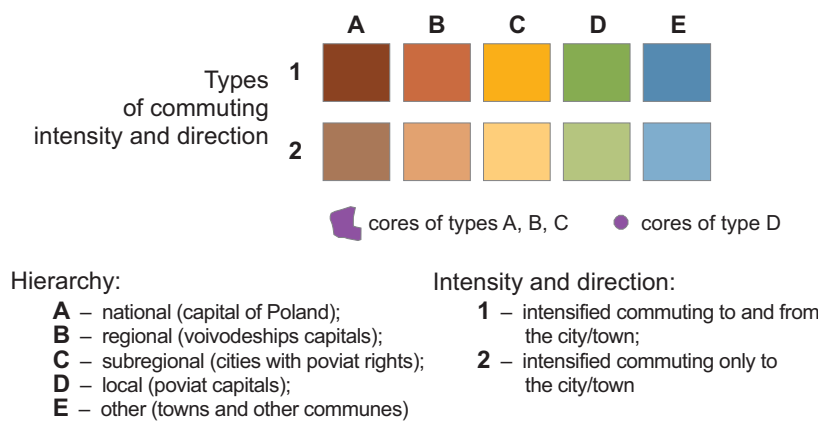

Number of employees

commuting between commune types

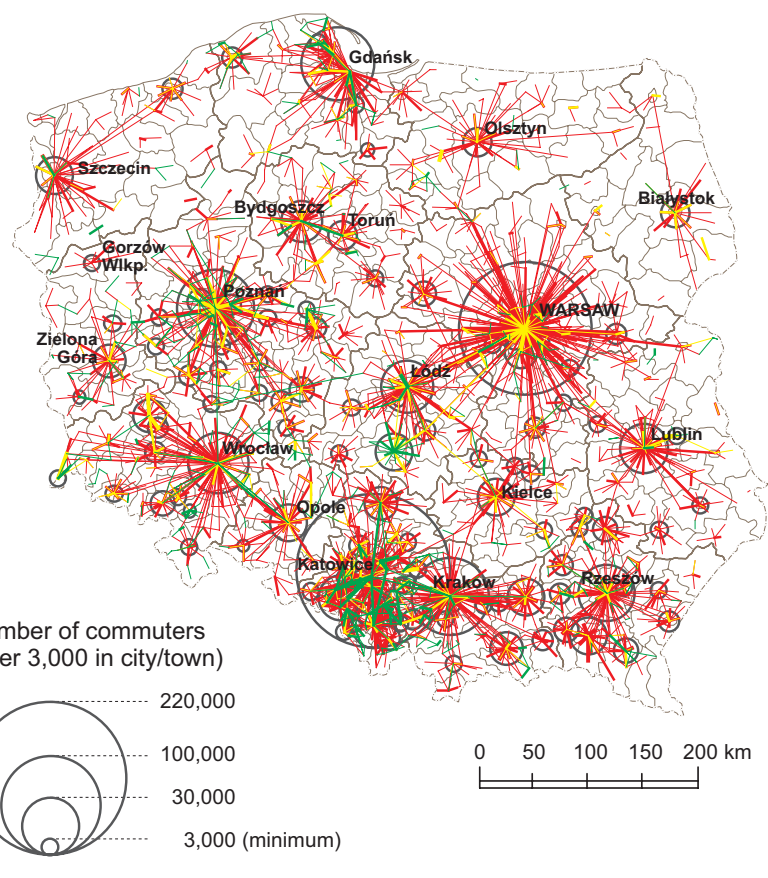

Size and direction of commuter flows between commune types - 100-300 - $301-1000-1001-8925$

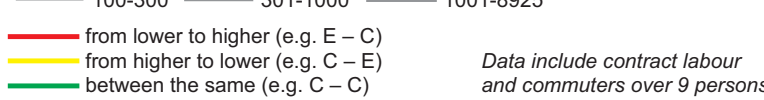

Fiand

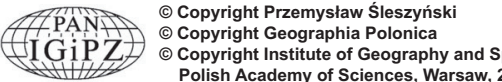

